Exploring the interactions among external reference price, social visibility and purchase motivation in pay-what-you-want pricing

Purpose - This paper investigates the direct and indirect effects of social visibility (private vs. public), purchase motivation (intrinsic vs. extrinsic vs. altruistic) and external reference price (absent vs. present) on consumers' pricing decisions in pay-what-you-want (PWYW) context.

Design/methodology/approach - Two empirical studies with a fitness gym as the research setting were used to test all the hypotheses; first, a lab experiment with undergraduate student participants and the second, an online experiment with a consumer panel.

Findings - Both studies show that consumers allocate a higher share (RATIO) of their internal reference prices (IRP) to the prices to be paid (PTP) in PWYW context, in private under intrinsic purchase motivation and in public under extrinsic or altruistic motivation; and this effect is more pronounced in the absence of external reference price (ERP).

Research limitations/implications - Future research may validate and extend our findings with other product or service categories, different manipulations for the key variables, other research methods such as field experiments and expand our model by including other relevant variables.

Practical implications - Our findings will help managers understand how individual customers' purchase motivation and the social visibility in the PWYW setting affect their pricing decisions and how providing external pricing cues may moderate these effects.

Originality/value - Prior research on PWYW shows mixed findings about the direct effects of many variables on consumers' pricing decisions but it ignores the differences in consumers' purchase motivations and offers mixed evidence about the influence of social visibility and external reference prices on payment decisions. We address all these gaps in this paper.

Keywords: External reference price, internal reference price, purchase motivation, social visibility, pay-what-you-want (PWYW), altruism, involvement, price consciousness

Article Classification: Research paper 


\section{Exploring the interactions among external reference price, social visibility and purchase motivation in pay-what-you-want pricing}

\section{Introduction}

With growing competition in the marketplace, innovative pricing strategies can be an effective way to create differentiation in the minds of consumers (Kim et al., 2009). Hence, companies have tried various 'participative' pricing mechanisms under which consumers may perceive to have more control over pricing decisions, which in turn may have a favorable impact on their purchase decisions (Chandran and Morwitz, 2005). Examples of such participative pricing strategies range from bidding models such as 'Name Your Own Price' (NYOP) (Chernev, 2003) and auctions (Dolan and Moon, 2000) to negotiated pricing (Dolan and Moon, 2000) and 'Pay What You Want' (PWYW) pricing (Gneezy et al., 2010; Gneezy et al., 2012; Kahsay and Samahita, 2015; Kim et al., 2014; Kim et al., 2009; Schmidt et al., 2014).

PWYW is different from other participative pricing mechanisms as it has no minimum price set by the seller and the buyers can pay whatever price they want (including a price of zero) that the seller has to accept without being able to withdraw the offer; whereas other participative pricing mechanisms such as auctions, negotiation and Name Your Own Price (NYOP) involve a series of interactions and negotiations between the buyers and the sellers along with a threshold price set by the seller (Kim et al., 2009); and the seller has the right to withdraw the product offer if the buyer offers a price below the seller's threshold price (Kim et al., 2009).

PWYW has drawn attention from marketing scholars (Gneezy et al., 2010; Gneezy et al., 2012; Kim et al., 2014; Kim et al., 2009; Schmidt et al., 2014) albeit with many mixed results, hence there is little conceptual clarity about the process by which consumers decide what price to 
pay (Gap 1). For example, Kim et al. (2009) found significant effects of each variable in their study (i.e., fairness, altruism, satisfaction, loyalty, price-consciousness, income, and reference price) on PWYW decisions, in only one of their three research settings (restaurant, cinema and delicatessen). Similarly, studies show either a positive (Kim et al., 2009), negative (Gneezy et al., 2012) or even no effect (Machado and Sinha, 2012) on the impact of social visibility (private vs. public) on PWYW pricing decisions. We address this gap with a new conceptual framework with 'purchase motivation' (intrinsic, extrinsic or altruistic) as a moderator of the process by which social visibility may influence consumers' pricing decisions. We argue that consumers would be willing to pay more in PWYW context, under the influence of intrinsic motivation in private and extrinsic or altruistic motivation in public.

Early PWYW research explored the role of internal reference prices (Kim et al., 2009) but recent studies also examined the role of external reference prices (ERP), albeit again with mixed results (Gap 2). For example, Kim et al. (2014) show a positive effect of ERP on prices paid by consumers and Schmidt et al. (2014) find a negative effect, whereas Johnson and Cui (2013) show both positive and negative effects for different types of ERP (minimum, maximum and suggested). As a result, it is not clear if using ERP will make consumers pay more or less and if this effect is contingent upon any other variables. We address this gap by proposing that ERP may actually play a more complex role than having a simple direct effect on PWYW prices, and instead it may interact with other variables such as social visibility (public vs. private) and consumers' purchase motivation (intrinsic vs. extrinsic vs. altruistic). We posit that providing ERP would weaken the interactive effect of social visibility and purchase motivation on consumers' pricing decisions in PWYW context. 
We tested and found support for most of our hypotheses with two studies, a lab experiment and an online experiment, both using a fitness gym context, which is different from the settings used in prior PWYW research. We extend current research on PWYW pricing and help resolve some inconclusive findings reported earlier (e.g., Gneezy et al., 2012; Kim et al., 2014; Kim et al., 2009; Machado and Sinha, 2012), by looking beyond the direct effects of variables such as altruism, fairness, price consciousness and reference price, to introduce a more comprehensive model incorporating two-way and three-way interactions. In the process, we aim to help future researchers and businesses interested in this innovative pricing strategy.

\section{Theoretical background and hypotheses}

Pay what you want (PWYW) pricing

PWYW pricing strategy has several benefits for the consumers and marketers (Kunter, 2015; Mendoza-Abarca and Mellema, 2015; Schmidt et al., 2014). First, it allows consumers to participate actively in the price-setting process giving them more perceived control, which in turn may lead to higher purchase intentions (Kim et al., 2009). Second, consumers may also have greater perceptions of fairness and satisfaction when they play an active role in the price setting process (Haws and Bearden, 2006). Third, PWYW allows for heterogeneous valuations and individually differentiated prices for the consumers (Spann and Tellis, 2006). Finally, PWYW pricing also allows the sellers to attract more buyers and serve consumer segments (e.g., price conscious) who would be otherwise priced out of the market (Kim et al., 2009).

Although buyers can pay any range of price under PWYW (including zero), the successful implementation of this pricing mechanism in both online and offline situations shows that consumers behave seemingly irrationally contrary to what standard economic theories would 
predict. Specifically, standard economic theories posit that consumers would maximize their utility function by paying nothing; past research shows that they rarely do so (Bertini and Koenigsberg, 2014; Gneezy et al., 2010; Kim et al., 2009). Researchers explain this apparently irrational behavior by suggesting that consumers are also guided by social exchange norms and not just money-market relationships (Ariely et al., 2009; Gneezy et al., 2012; Kahsay and Samahita, 2015; Mendoza-Abarca and Mellema, 2015; Riener and Traxler, 2012).

In money-market relationships, exchange between two parties is governed by the use of a value or utility metric while social-market relationships are guided by social exchange norms driven by considerations such as reciprocity, cooperation and distribution (Heyman and Ariely, 2004). Consumers are generally unwilling to violate social norms as such actions may result in social disapproval and personal distress (Ariely et al., 2009). PWYW pricing invokes social exchange norms by dissolving typical money-market relationships as buyers are allowed to have maximum control over pricing decisions, which leads to many consumers paying a price higher than zero (Kim et al., 2009; Riener and Traxler, 2012). In this context, we next discuss the role of reference prices on consumers' PWYW pricing decisions.

\section{Internal reference price (IRP)}

Internal reference price (IRP) is defined as a memory-resident price based on actual, fair, or other price concepts (Garbarino and Slonim, 2003), which the consumers use as an internal judgment scale to evaluate the prices offered to them (Mazumdar et al., 2005; Winer, 1986). Consumers may also draw on their memory for prices paid by them in the past for a similar product or service, when they are in a purchase environment (Mazumdar and Papatla, 2000). In PWYW context, consumers often rely on IRP because as a memory-based cue it may help them 
decide the price they are willing to pay (Kim et al., 2009). For example, Kim et al. (2009) used a series of field experiments in different PWYW settings (restaurant, cinema and delicatessen) to show that buyers are willing to discharge a higher proportion of their internal reference price (IRP) to the seller in all the three settings. Similar results are reported by other researchers (e.g., Kahsay and Samahita, 2015; Roy, 2015), hence we use the ratio of prices to be paid and IRP (i.e., the allocation of internal reference price) as the dependent variable in this study.

\section{Social Visibility - Private vs. Public}

People like to be seen by others while doing good because they are concerned about what others may think about their observed behavior (Ariely et al., 2009). For example, people act more prosocially (i.e., donate more money) in public than in private during charitable fund-raising events (Andreoni and Petrie, 2004; Soetevent, 2005). Consumers are also less price-sensitive and pay more in social settings than in private (Wakefield and Inman, 2003). In PWYW, Kim et al. $(2009$, p.47) show that social visibility (face-to-face interaction with the seller) makes consumers pay more than a price of zero because "most consumers will conform to social norms and may not want to appear cheap". Others report similar results (e.g., Kunter, 2015; Mendoza-Abarca and Mellema, 2015; Riener and Traxler, 2012) based on which we hypothesize:

H1: Social visibility has a positive effect on the allocation of IRP to the prices to be paid (PTP) by the consumers in PWYW context, such that RATIO (PTP/IRP) is higher under public versus private settings.

\section{Purchase motivation - intrinsic, extrinsic and altruistic}

Early research identified two types of motivations that drive human behavior in a given situation; intrinsic (e.g., health, well-being and personal growth) and extrinsic (e.g., financial success, fame 
and physical appearance) motivations (Ryan and Deci, 2000). Under intrinsic motivation people focus on the task itself and on consequences external to the task such as receiving rewards or avoiding punishment, under extrinsic motivation. People are also more oriented towards interpersonal comparisons and pursuit of the right social image and status under extrinsic motivation (Kasser et al., 2004). In other words, extrinsic motives can motivate people to present themselves in line with popular social norms, which may even undermine their intrinsic motives. For example, giving external motivation in the form of rewards to undertake an intrinsically interesting activity can lead to less enjoyment (Deci, 1972). In the pricing context, consumers are also influenced by how they want to appear to themselves i.e. self-image (intrinsic) or to others i.e. social image (extrinsic) (Aronson and Aronson, 2007).

Subsequent researchers introduced altruistic motivation as a construct distinct from the intrinsic and extrinsic motivations. Altruism involves different types of non-egoistic motives and behaviours (Lynn and Oldenquist, 1986; cf. Rushton and Sorrentino, 1981) that may be linked to both intrinsic and extrinsic motive. For example, the 'warm-glow' altruism (Adreoni, 1990) parallels the notion of intrinsic satisfaction (De Young, 1996) whereas 'paternalistic' altruism $\underline{\text { (McConnell, 1997) }}$ arises when people are concerned about the satisfaction of others (Clark, Kotchen and Moore, 2003). There is mixed evidence about the origins of altruistic motivation and behaviour. For example, similar to intrinsic motivation, external rewards may undermine altruistic motivation to help others (Kunda and Schwartz, 1983), whereas others question the existence of pure altruism and claim that it is driven by ego needs or self-reward (Cialdini 1991; Crumpler and Grossman, 2008). Notwithstanding the origin of altruistic motivations, there is substantial evidence about their influence on peoples' attitudes and behaviours towards charitable causes, wherein people use charity to signal a desirable social-image and to seek social 
approval, and thereby end up donating more money in the process of doing so, especially in public than in private (Andreoni and Petrie, 2004; Soetevent, 2005).

\section{Interaction between social visibility and purchase motivation}

Recent research on the role of social motivations on PWYW pricing decisions shows mixed results. For example, Gneezy et al. (2012) found a negative effect of social visibility on the prices paid by the consumers in three different settings (theme park, tour boat and restaurant) wherein the consumers paid higher prices in private than in public, whereas Machado and Sinha (2012) did not find any effect of social visibility on PWYW prices. In this context, Gneezy et al. (2012) explain their findings by arguing that consumers may be more concerned about their selfimage rather than their social-image and hence, they would pay more to protect their self-image. In contrast, Machado and Sinha (2012) explain the lack of any significant difference simply as an artifact of the experimental setting because the payment was only visible to a lab assistant with whom most participants would not expect any future interactions. Interestingly, when they tested their model with only the non-zero payments from their sample, they did find a positive effect of payment visibility as shown by significantly lower payments in the private condition. We extend this line of research by proposing that consumers' inherent purchase motivation (intrinsic, extrinsic or altruistic) may moderate the impact of social visibility on their PWYW decisions.

In the case of consumers who are influenced by intrinsic motives, their personal values and self-image may drive the amount of money paid (Gneezy et al., 2012; Kahsay and Samahita, 2015); whereas for those influenced by extrinsic motives, the presence of others around them and perceived social impact may play a greater role (Kim et al., 2009; Kunter, 2015; MendozaAbarca and Mellema, 2015). In other words, we expect that consumers would be influenced by 
personal goals such as self-image and adherence to personal values to a greater extent when they are alone (private) than with others (public); and more by social goals such as social-image and impression management in the company of others (public) than when they are alone (private).

We further argue that the impact of altruistic motivation on PWYW pricing decisions would be stronger in public than in private. People with altruistic motives want to signal desirable image while making donations to charity, and may pay more money in public than in private (Andreoni and Petrie, 2004; Soetevent, 2005). Similarly, past research on PWYW shows that people may try to signal a positive image to others and pay more in public than in private (Gneezy et al., 2012). Due to the ability of altruistic behaviour in helping people make a good impression on others, altruistic motivation should have a stronger influence on PWYW pricing decisions in public than in private. Based on the above, we hypothesize as follows:

H2: Purchase motivation moderates the effect of social visibility on the allocation of IRP to the prices to be paid (PTP), such that PTP/IRP ratio is a) higher in private than in public under the influence of intrinsic motivation, and higher in public than in private under the influence of b) extrinsic, and c) altruistic motivations.

\section{External reference price (ERP)}

External reference prices (ERP) are based on the external stimuli in the purchase environment, such as suggested retail prices or regularly offered prices, and consumers use these along with IRP to make their purchase decisions (Mazumdar and Papatla, 2000). Early PWYW research focused on the impact of IRP on consumers' pricing decision (e.g., Kim et al., 2009) but recent studies have explored the role of ERP albeit with inconclusive findings. For example, Kim et al. (2014) show that the existence of ERP positively affects prices paid by the consumers in a 
PWYW setting because ERP acts as a normative anchor influencing consumers to pay close to the posted price. In contrast, Schmidt et al. (2014) find that a posted price as ERP may reduce the buyers' payments by acting as an upper bound on the PWYW payments.

To further explore the role of ERP in PWYW pricing, Johnson and Cui (2013) evaluate three types of ERP strategies used by marketers to influence consumers' PWYW pricing decisions, namely minimum, maximum, and suggested prices. Interestingly, they also find mixed results, wherein both minimum and maximum prices as ERP show a negative impact on prices paid by the consumers, whereas suggested price helps maximize the firm's yield by allowing consumers to choose their own price, especially when the suggested price is close to the consumer's IRP. From such mixed findings, it is clear that there is a need to look deeper into the process by which ERP affects consumers' pricing decisions in PWYW context. We address this need by looking beyond the direct effects of ERP on prices paid by the consumers in a PWYW setting and investigating the interaction of ERP with purchase motivation and social visibility, while controlling for various other variables including internal reference price.

We argue that the hypothesized interaction between purchase motivation and social visibility (H2) would no longer hold when ERP is provided, for two reasons. First, when external price information is provided, consumers will have an objective anchor to help them make their pricing decision and they will no longer be driven by extrinsic factors such as impression management or intrinsic factors such as self-image or personal values. Second, having ERP as an external anchor will also help the consumers arrive at their pricing decision in a relatively more objective manner and reduce the impact of a subjective factor such as social visibility (private vs. public). Moreover, similar to the impact of intrinsic and extrinsic motivations, we expect this difference in the impact of altruistic motivation between public and private to be stronger in the 
absence of ERP than in its presence. This follows from our above argument that even altruistic behaviour can be driven by subjective factors such as image and social motives (Andreoni and Petrie, 2004; Soetevent, 2005) and such motives diminish when consumers rely on objective rather than subjective factors. Based on this reasoning, we put forth our final hypothesis:

H3: The two-way interaction between purchase motivation and social visibility would become non-significant when ERP is provided, such that the differences in the effects of a) intrinsic, b) extrinsic and c) altruistic motivations on PTP/IRP ratio in private versus public are stronger in the absence of ERP than in its presence.

Figure I depicts all these hypotheses. Next we describe two studies (a lab experiment and an online experiment) used to test these hypotheses. In particular study 1 tests $\mathrm{H} 1, \mathrm{H} 2 \mathrm{a}, \mathrm{H} 2 \mathrm{~b}$, H3a and H3b. Study 2 tests all the hypotheses (i.e., H1, H2a-c and H3a-c).

$<$ Insert Figure I about here >

\section{Study 1 - Lab Experiment}

\section{Sample and procedure}

We used a 2 (purchase motivation: intrinsic, extrinsic) x 2 (social visibility: friends, alone) x 2 (ERP: present, absent) mixed experimental design with the first two factors manipulated as between-subjects and the third factor as a within-subject variable. 124 students (65 females) participated in the lab experiment and were randomly assigned to one of the eight experimental conditions. $89 \%$ of the respondents are in the age group of $19-30$ years. Table I summarizes the sample characteristics for both the studies.

\footnotetext{
$<$ Insert Tables I about here $>$
} 
All the participants completed a structured questionnaire with three parts. In the first part, the participants were asked to imagine that they were planning to join a fitness gym on the campus that had come up with a special one week PWYW offer. We then manipulated purchase motivation by asking participants to imagine that the reason for joining the gym was to improve their fitness (intrinsic) or to look good (extrinsic) for an upcoming bike trip. Next, we manipulated social visibility by asking the participants to imagine that while making payment at the gym they were either alone or with a group of friends. We then checked the manipulations by using adapted multiple-item scales for intrinsic/extrinsic motivation (Ryan and Deci, 2000) and social visibility (Sharma, 2011). Finally, the participants recorded the price they would pay (PTP1) followed by their IRP (normal price for a similar offer).

In the second part, participants were given the external reference price (ERP) by informing them that a similar one week trial was normally offered for AU\$ 15 . We finalized the ERP amount based on an informal survey of prices for similar offers at local gyms and a pretest with students from the same cohort. Next, the participants reported the price they would pay (PTP2) based on this new information. Finally, the participants completed the scales for price consciousness (Donthu and Gilliland, 1996), involvement (Sharma, 2011) and social desirability (Hays et al., 1989), followed by the demographic variables (age, gender and monthly expenses).

\section{Data analysis and results}

We began by testing the measurement model using Confirmatory Factor Analysis with AMOS 22.0 and found a close fit $\left(\chi^{2}=173.77, d f=122, \chi^{2} / d f=1.42, \mathrm{NFI}=.90, \mathrm{CFI}=.96, \mathrm{RMSEA}=\right.$ .058 and SRMR $=.056)$ with all the fit indices better than the recommended cut-off values. All the parameter estimates are high $(.71-.95)$ and load significantly $(\mathrm{p}<.001)$ on their respective 
expected latent constructs with no major cross-factor loadings. Average variance extracted (AVE) for all the scales (.54-.75) and the construct reliabilities $(.76-.94)$ are also quite high. Table II shows the descriptive statistics for all the scale items and Table III shows the correlations and psychometric properties for all the constructs.

$<$ Insert Tables II and III about here $>$

We checked our manipulations using multivariate analysis of variance (MANOVA) with the average scores for social visibility and purchase motivations as dependent variables, the two experimental conditions ('private vs. public' and 'intrinsic vs. extrinsic') as the fixed factors and the control variables as covariates. We found significantly higher scores for the social visibility scale under public $(M=4.57)$ versus private $(M=3.72)$ conditions $(F(1,123)=7.39, p<.01)$, for intrinsic motivation under intrinsic $(M=5.89)$ versus extrinsic $(M=4.73)$ conditions $(F(1,123)$ $=53.74, \mathrm{p}<.001)$; and for extrinsic motivation under extrinsic $(\mathrm{M}=5.71)$ vs. intrinsic $(\mathrm{M}=4.68)$ conditions $(\mathrm{F}(1,123)=31.88, \mathrm{p}<.001)$. Thus, both manipulations are successful.

Next, as advised in extant literature (e.g., Kim et al., 2014), we created two ratios, RATIO1 (PTP1/IRP) and RATIO2 (PTP2 /IRP) by dividing the two 'prices to be paid' (PTP) measures by IRP, in order to control for IRP and to achieve comparability across the two PTP measures with and without ERP. We then used a three-way mixed ANOVA with RATIO1 and RATIO2 as within-subject dependent variables and the two manipulated variables (purchase motivation and social visibility) as between-subjects factors, to test all our hypotheses. We also included involvement, social desirability and price consciousness (and its interactions with all the manipulated variables) as covariates. Table IV and Figure II summarize these results.

$<$ Insert Table IV and Figure II about here $>$ 
We first looked at the findings for the between-subjects factors and found no significant difference in RATIO1 under private $(\mathrm{M}=0.93)$ versus public $(\mathrm{M}=0.94)$ condition $(\mathrm{F}(1,89)=1.02$, $\mathrm{p}>.31$ ), thus H1 is not supported. Similarly, there is no significant difference in the value of RATIO1 $(F(1,89)=0.42, p>.52)$ between intrinsic $(M=0.89)$ and extrinsic $(M=0.97)$ purchase motivation. Next, we found a significant two-way interaction between purchase motivation and social visibility $(F(1,89)=6.089, p<0.05)$, showing that in the absence of ERP, intrinsically motivated consumers allocate a higher proportion of their internal reference price in private $(\mathrm{M}=1.30)$ versus public $(\mathrm{M}=0.51)$ condition $(\mathrm{H} 2 \mathrm{a})$; whereas extrinsically motivated consumers are willing to allocate a higher proportion of their internal reference price in public $(\mathrm{M}=1.40)$ versus Private $(\mathrm{M}=0.59)$ condition $(\mathrm{H} 2 \mathrm{~b})$. Hence, these findings support both $\mathrm{H} 2 \mathrm{a}$ and $\mathrm{H} 2 \mathrm{~b}$.

Next, we checked the within-subject effects and found no significant main effect of RATIO (Wilk's Lambda $=0.99, \mathrm{~F}(1,89)=0.56, \mathrm{p}>0.45)$ or its interactions with purchase motivation (Wilk's Lambda $=1.00, \mathrm{~F}(1,89)=0.12, \mathrm{p}>0.66)$, social visibility (Wilk's Lambda $=$ $0.99, \mathrm{~F}(1,89)=1.23, \mathrm{p}>0.27)$ and all the control variables. However, as expected, the three-way interaction among RATIO, purchase motivation and social visibility is significant (Wilk's Lambda $=0.96, \mathrm{~F}(1,89)=4.12, \mathrm{p}<0.05)$, which means that in the presence of ERP there is no significant difference in the value of RATIO in private $(M=0.62)$ versus public $(M=0.59)$ under intrinsic motivation (H3a) although it is still higher in public $(\mathrm{M}=1.06)$ versus private $(\mathrm{M}=0.47)$ under extrinsic motivation (H3b). Hence, $\mathrm{H} 3 \mathrm{a}$ is supported and $\mathrm{H} 3 \mathrm{~b}$ is not, but overall these findings show that the interaction between social visibility and purchase motivation becomes non-significant under the presence of ERP. Finally, among all the covariates, only priceconsciousness shows a positive effect $(\mathrm{F}(1,89)=4.06, \mathrm{p}<.05)$ and there is no change in our results with or without any of the control variables or their interactions. 


\section{Discussion}

In study one, we used a lab experiment in the context of a fitness gym on campus, to probe the direct and indirect effects of purchase motivation and social visibility on PWYW pricing decisions, while controlling for various individual characteristics used in past research (e.g., involvement, price consciousness and social desirability). As hypothesized, social visibility interacts with purchase motivation to influence payment decisions in the absence of ERP and this interaction disappears when ERP is provided to the consumers prior to making payments. This finding has important implications because it may help resolve the ambiguity in prior research about the role of ERP on consumers' PWYW decision-making. Our results show that ERP may not directly influence prices paid by consumers but it may indirectly influence this process by interacting with other important variables such as social visibility and purchase motivation. Therefore, marketers should be careful about using ERPs in the form of regular prices or other external pricing cues because it may either decrease or increase the prices paid by consumers depending on whether they are intrinsically or extrinsically motivated and if they are alone or in company of others (which may affect their susceptibility to others' influence).

Notwithstanding the above useful insights, our first study has a few limitations. First, we used undergraduate students as participants with a fitness gym on campus as the PWYW setting that was found to be highly relevant to these students based on our pretest with a smaller group of students from the same cohort. However, our sample is relatively younger and has quite low disposable income; hence our findings may not be generalizable to the broader consumer population. Moreover, we did not collect information on the past membership and recent usage of fitness gyms, hence we could not control the effects of these variables on our results. 
Second, we used a within-subject design to explore the impact of ERP on the interaction between social visibility and purchase motivation, which were manipulated between-subjects. As a result, we used a three-way mixed ANOVA to test the influence of ERP on our other variables and their interactions. However, it may be more rigorous to use a between-subjects design to manipulate the absence and presence of ERP to avoid any carry-over or demand effects. Third, we use two types of purchase motivation (intrinsic and extrinsic) in our first study but it would be useful to explore the impact of altruistic motivation on PWYW pricing decisions in view of unclear results on the role of altruism reported in prior PWYW research (e.g., Kim et al., 2009).

We address all these limitations in our second study by using an online experiment with a between-subjects design, again with a 'fitness gym' as the PWYW setting and 'friends' to manipulate the public condition in order to be consistent with our first study. We also collected past membership and usage frequency of a fitness gym and used these as control variables. Finally, we included an altruistic (i.e., charitable) purchase motivation in order to compare its impact with that of the other two motivations (intrinsic and extrinsic) included in our first study.

\section{Study 2 - Online Experiment}

\section{Sample and procedure}

We used a 3 (purchase motivation: intrinsic, extrinsic, altruistic) x 2 (social visibility: friends, alone) x 2 (ERP: present, absent) between-subjects experimental design with 435 members of an Australian online consumer panel (197, $45 \%$ females) who were randomly assigned to one of the twelve experimental conditions. This sample is quite different from our first study as it has no students and all the respondents are above the age of 21 years, most $(88 \%)$ have an income higher than AU\$ 1,000 per month, about 59\% are employed and the rest are unemployed (13\%), 
retired $(14 \%)$, housewives $(8 \%)$ or others $(6 \%)$. More than half $(53 \%)$ had a gym membership in the past and about half (52\%) have never used a fitness gym.

All the participants completed an online questionnaire similar to the one in study one. On the first screen, they read a scenario about a special one week PWYW offer from a fitness gym near their home under which they can pay any price they want (including a price of zero) and the gym promises to donate all their collections from this offer to a local charity. To manipulate the absence and presence of ERP, half the scenarios mentioned that a similar offer was available for AU $\$ 15$ at other gyms whereas the other half of scenarios did not include any such information. We then manipulated social visibility by asking the participants to imagine that while making payment at the gym they were either alone or with a group of friends. Next, we manipulated purchase motivation by asking the participants to imagine one of these for joining the gym - to improve fitness and stamina for a healthy lifestyle (intrinsic), to improve physical appearance to impress friends (extrinsic) or to make a useful contribution to the society (altruistic).

Next, we then checked the manipulations with the adapted scales for intrinsic, extrinsic and altruistic motivations (Ryan and Deci, 2000) and social visibility (Sharma, 2011). The participants then recorded the price they would pay (PTP) for the PWYW offer followed by their IRP (normal price for a similar offer at any other gym). Finally, the participants completed the price consciousness (Donthu and Gilliland, 1996), involvement (Sharma, 2011) and social desirability (Hays et al., 1989) scales, followed by the demographic variables (age, gender, income, occupation, past gym membership and current usage).

Data analysis and results 
We began by testing the measurement model using Confirmatory Factor Analysis with AMOS 22.0 and found a close fit $\left(\chi^{2}=393.37, d f=187, \chi^{2} / d f=2.13, \mathrm{NFI}=.96, \mathrm{CFI}=.98, \mathrm{RMSEA}=\right.$ .051 and SRMR $=.044)$ with all the fit indices better than the recommended cut-off values. All the parameter estimates are high $(.71-.95)$ and load significantly $(p<.001)$ on their respective latent constructs as expected with no major cross-factor loadings. All the scales also show high average variance extracted (AVE) $(.71-.84)$ and the construct reliabilities $(.90-.97)$ are also quite high. Table V shows the descriptive statistics for all the scale items and Table VI shows the correlations and psychometric properties for all the constructs.

\section{$<$ Insert Tables V and VI about here $>$}

We used multivariate analysis of variance to check our manipulations by comparing the average scores for social visibility and purchase motivation across the experimental conditions. We found significantly higher scores for social visibility in public $(M=4.67)$ than in private $(\mathrm{M}=4.04)$ conditions $(\mathrm{F}(1,435)=16.36, \mathrm{p}<.001)$; for intrinsic motivation under intrinsic $(M=5.31)$ than in extrinsic $(M=4.32)$ and altruistic $(M=4.16)$ conditions $(F(2,435)=20.80, p<$ $.001)$; for extrinsic motivation under extrinsic $(M=4.05)$ than in intrinsic $(M=2.95)$ and altruistic $(\mathrm{M}=3.08)$ conditions $(\mathrm{F}(2,435)=18.61, \mathrm{p}<.001)$; and for altruistic motivation under altruistic $(\mathrm{M}=5.30)$ than in intrinsic $(\mathrm{M}=4.13)$ and extrinsic $(\mathrm{M}=4.00)$ conditions $(\mathrm{F}(2,435)=26.41, \mathrm{p}<$ .001). Based on these results, all the manipulations appear to be successful.

We used a three-way analysis of variance (ANOVA) to test all the hypotheses because in this study we manipulated ERP, purchase motivation and social visibility as between-subjects factors. Hence, we calculated RATIO by dividing the price to be paid (PTP) by the internal reference price (IRP) and used it as the dependent variable, along with the three manipulated 
variables (ERP, social visibility and purchase motivation) as the fixed factors, and involvement, social desirability and price consciousness (and its interactions with all the manipulated variables) as covariates, as in the first study. Table VII and Figure III summarize the results.

$<$ Insert Table VII and Figure III about here $>$

We looked at the main effects of social visibility and purchase motivation by comparing the value of RATIO across the different conditions for these two variables. Once again we found no significant differences in the values of RATIO under private $(\mathrm{M}=0.95)$ and public $(\mathrm{M}=0.95)$ conditions $(F(1,435)=0.001, p>.97)$, thus $H 1$ is again not supported. Similarly, there is no significant difference in the values of RATIO between intrinsic $(\mathrm{M}=1.03)$, extrinsic $(\mathrm{M}=0.82)$ and altruistic $(M=1.00)$ purchase motivations $(F(2,435)=1.03, p>.36)$. We found a significant two-way interaction between purchase motivation and social visibility $(F(2,435)=4.907, p<$ $0.01)$ with a higher value of RATIO in private $(\mathrm{M}=1.36)$ than in public $(\mathrm{M}=0.72)$ under intrinsic motivation $(\mathrm{H} 2 \mathrm{a})$ but a higher value in public than in private for extrinsic (H2b: M=0.89 vs. $0.74)$ and altruistic (H2c: $\mathrm{M}=1.23$ vs. 0.77$)$ motivations; hence $\mathrm{H} 2 \mathrm{a}, \mathrm{H} 2 \mathrm{~b}$ and $\mathrm{H} 2 \mathrm{c}$ are supported.

Next, the three-way interaction between ERP, purchase motivation and social visibility is also significant $(F(2,435)=3.91, p<0.05)$, with significantly greater difference in the value of RATIO in private and public under "ERP Absent" condition for intrinsic (H3a: 1.78-0.74= 1.04), extrinsic (H3b: 0.53-0.93 $=-0.40)$ and altruistic $(\mathrm{H3} \mathrm{c}: 0.68-1.72=-1.04)$ motivations, compared to the "ERP present" condition for intrinsic $(0.96-0.70=0.26)$, extrinsic $(0.96-0.85=$ $0.11)$ and altruistic $(0.85-0.77=0.08)$ motivations. Hence, $\mathrm{H} 3 \mathrm{a}, \mathrm{H} 3 \mathrm{~b}$ and $\mathrm{H} 3 \mathrm{c}$ are also supported. Finally, among all the covariates, only involvement shows a positive effect on RATIO $(\mathrm{F}(1,435)=5.71, \mathrm{p}<.05)$ and there is no impact of any control variables on our results. 


\section{General discussion}

\section{Conceptual contribution}

We used two studies to explore the direct and indirect impacts of social visibility and purchase motivation on the allocation of IRP into prices to be paid by the consumers in the absence and presence of ERP in a PWYW context. Using a fitness gym setting in both our studies (one a lab experiment and the other an online experiment), as expected we did not find any direct effect of social visibility and purchase motivation but we did find the hypothesized interaction between these two manipulated variables as well as a three-way interaction with ERP. Specifically, we did not find any significant difference in the allocation of IRP between private and public or under the influence of different purchase motivations as such but consumers did allocate a greater proportion of their IRP in private under intrinsic motivation and in public under extrinsic and altruistic motivation. All these differences are more pronounced in the absence of ERP and weaker in the presence of ERP. Overall, we provide useful insights into the socio-psychological mechanism underlying the consumer decision-making in PWYW context and make two main theoretical contributions.

First, we address the inconsistency in the literature regarding how social visibility may influence PWYW prices. For example, Kim et al. (2009) show a positive effect of social visibility on PWYW prices, Gneezy et al. (2012) show a negative effect, whereas Machado and Sinha (2012) show no significant effect. Our findings resolve this conflict by showing that instead of having a direct effect, social visibility may interact with consumers' purchase motivation (intrinsic vs. extrinsic) to influence the extent to which the consumers are willing to 
allocate their IRP to the prices they would pay. Thus, by studying the interaction between these variables, we address an important gap in the current research on PWYW pricing.

Second, we extend recent research (Johnson and Cui, 2013; Kim et al., 2014; Schmidt et al., 2014) that present contrasting results about the role of ERP in PWYW context. For example, Kim et al. (2014) show a positive effect of ERP on prices paid by consumers and Schmidt et al. (2014) find a negative effect, whereas Johnson and Cui (2013) show both positive and negative effects for different types of ERP (minimum, maximum and suggested). We address these mixed results by hypothesizing a three-way interaction among ERP, purchase motivation and social visibility. We then show in both our studies that the social forces (as operationalized by the interaction between social visibility and purchase motivation) are only at play in the absence of objective pricing cues (in the form of ERP) and the effects of this interaction disappear when consumers are provided with ERP information.

\section{Managerial implications}

Our research also has important managerial implications. First, our findings show that intrinsic purchase motivation has a stronger influence in private than in public, whereas extrinsic purchase motivation has a stronger influence in public than in private. Hence, service provider using PWYW pricing should emphasize the intrinsic elements of their service (e.g., quality of dining for a restaurant or the quality of personal training for a fitness gym) to customers who are alone or making the payments on their own in order to encourage such consumers to pay more. In contrast, for customers who are with others (e.g., colleagues, friends or family), it may be a good idea to draw their attention to extrinsic factors such as, how others have enjoyed dining at the 
restaurant or getting a toned body by exercising in the gym, possibly by displaying pictures and testimonials from satisfied, happy and smiling customers.

We also found that altruistic motivations have a stronger impact on the prices paid by the customers when there is a charitable outcome (e.g., a voluntary donation by the seller from the money paid by the customers) attached with the service, in public than in private. Hence, PWYW sellers could associate with social and charitable causes to in order to motivate their customers to pay more for their services, especially when their services are usually consumed in public, such as cafes, restaurants etc. PWYW businesses can also display names of regular patrons on their websites as such public visibility may encourage customers to pay more (Andreoni and Petrie, 2004). Finally, we show that the interaction between social visibility and purchase motivation is stronger in the absence of ERP than in its presence. Hence, firms using PWYW pricing should exercise caution in providing external price references especially when customers ask how much others had paid for the same product or service (e.g., Machado and Sinha, 2012), because this may have an attenuating effect on the prices paid by them or even make some of them decide not to purchase (Gneezy et al., 2010). In this context, it would be useful to direct the attention of the customers towards the intrinsic benefits of the product or service when the payment is being made in private and the extrinsic or altruistic benefits when the payment is being made in public.

\section{Limitations and future research}

Our research has a few limitations that may be addressed in future research. First, we used the same fitness gym setting in both our studies in order to be consistent and to replicate our results using different study designs to manipulate ERP as a within-subjects variable in study one and as a between-subjects variable in study two. However, this may limit the generalizability of our 
findings to other products and services, hence future research may test our model in other research settings that have been used in prior research, such as café, restaurant and cinema (Kim et al., 2009). Second, in both our studies we control for variables such as involvement, price consciousness and social desirability because these were found to have an impact on consumers' PWYW pricing decisions in past research. However, there are other variables such as altruism, fairness, satisfaction and loyalty that were used in some studies; hence future research could include these and other relevant variables (e.g., self-image, personal values and cultural orientations) to further investigate the mechanisms underlying pricing decisions under the impact of purchase motivation and social visibility. Third, we operationalize social visibility through friends in both our studies, which may limit the generalizability of our results. Hence, future studies may manipulate this variable with colleagues, family members and even strangers, in order to tap into a wider range of familiarity. Further, our measure of internal reference price could have been influenced by subjects' PTP, as this was recorded immediately after participants reported their prices for the PWYW offer. Future research may create a separation between these two measurements in order to ensure their independence from each other. Finally, in a recent study on the impact of ERP, Johnson and Cui (2013) show that minimum and maximum prices have a negative influence on prices but a suggested price strategy helps the PWYW firms maximize their yield. Hence, future research may also explore the influence of different levels of ERP on the interaction between social visibility and purchase motivation. 


\section{References}

Andreoni, J. (1990), "Impure altruism and donations to public goods: A theory of warm-glow giving", The Economic Journal, Vol. 100 No. 401, pp. 464-477.

Andreoni, J., and Petrie, R. (2004), "Public goods experiments without confidentiality: a glimpse into fund-raising”, Journal of public Economics, Vol. 88 No. 7, pp.1605-1623.

Ariely, D., Bracha, A. and Meier, S. (2009), "Doing good or doing well? Image motivation and monetary incentives in behaving prosocially", The American Economic Review, Vol. 99 No. 1, pp. 544-555.

Aronson, E., and Aronson, J. (2007), The social animal, New York: Worth Publishers.

Bertini, M. and Koenigsberg, O. (2014). When Customers Help Set Prices. MIT Sloan Management Review.

Cialdini, R.B. (1991), "Altruism or egoism? That is (still) the question", Psychological Inquiry Vol. 2 No. 2, pp. 124-126.

Chandran, S. and Morwitz, V.G. (2005), "Effects of participative pricing on consumers' cognitions and actions: A goal theoretic perspective", Journal of Consumer Research, Vol. 32 No. 2, pp. 249-259.

Chernev, A. (2003), "Reverse pricing and online price elicitation strategies in consumer choice", Journal of Consumer Psychology, Vol. 13 No. 1, pp. 51-62.

Clark, C. F., Kotchen, M. J., and Moore, M. R. (2003), "Internal and external influences on proenvironmental behavior: Participation in a green electricity program", Journal of environmental psychology, Vol. 23 No. 3, pp. 237-246.

Crumpler, H. and Grossman, P.J. (2008), "An experimental test of warm glow giving." Journal of public Economics, Vol. 92 No. 5, pp. 1011-1021.

Deci, E.L. (1972), "Intrinsic motivation, extrinsic reinforcement, and inequity", Journal of personality and social psychology, Vol. 22 No. 1, pp. 113-120.

De Young, R. (1996), "Some psychological aspects of reduced consumption behaviour: The role of intrinsic satisfaction and competence motivation”, Environment and Behaviour, Vol. 28 No. 3, pp. 358-409.

Dolan, R.J. and Moon, Y. (2000), "Pricing and market making on the Internet", Journal of Interactive Marketing, Vol. 14 No. 2, pp. 56-73.

Donthu, N. and Gilliland, D. (1996), "Observations: The infomercial shopper", Journal of Advertising Research, Vol. 36 No. 2, pp. 69-76. 
Garbarino, E. and Slonim, R. (2003), "Interrelationships and distinct effects of internal reference prices on perceived expensiveness and demand", Psychology \& Marketing, Vol. 20 No. 3, pp. 227-248.

Gneezy, A., Gneezy, U., Nelson, L.D. and Brown, A. (2010), "Shared social responsibility: A field experiment in pay-what-you-want pricing and charitable giving", Science, Vol. 329 No. 5989, pp. 325-327.

Gneezy, A., Gneezy, U., Riener, G. and Nelson, L.D. (2012), "Pay-what-you-want, identity, and self-signaling in markets", Proceedings of the National Academy of Sciences, Vol. 109 No. 19, pp. 7236-7240.

Haws, K.L. and Bearden, W.O. (2006), "Dynamic pricing and consumer fairness perceptions", Journal of Consumer Research, Vol. 33 No. 3, pp. 304-311.

Hays, R.D., Hayashi, T. and Stewart, A.L. (1989), "A five-item measure of socially desirable response set", Educational and psychological measurement, Vol. 49 No. 3, pp. 629-636.

Heyman, J. and Ariely, D. (2004), "Effort for payment a tale of two markets", Psychological science, Vol. 15 No. 11, pp. 787-793.

Johnson, J.W. and Cui, A.P. (2013), "To influence or not to influence: External reference price strategies in pay-what-you-want pricing", Journal of Business Research, Vol. 66 No. 2, pp. 275-281.

Kahsay, G.A. and Samahita, M. (2015), "Pay-What-You-Want pricing schemes: A self-image perspective", Journal of Behavioral and Experimental Finance, Vol. 7 No. 1, pp. 17-28.

Kasser, T., Ryan, R.M., Couchman, C.E. and Sheldon, K.M. (2004), "Materialistic values: Their causes and consequences", In: Kasser, T. and Kanner, A.D. (eds.) Psychology and consumer culture: The struggle for a good life in a materialistic world. Washington DC, US: American Psychological Association, pp. 11-28.

Kim, J.-Y., Kaufmann, K. and Stegemann, M. (2014), "The impact of buyer-seller relationships and reference prices on the effectiveness of the pay what you want pricing mechanism", Marketing Letters, Vol. 25 No. 4, pp. 409-423.

Kim, J.-Y., Natter, M. and Spann, M. (2009), "Pay what you want: A new participative pricing mechanism", Journal of Marketing, Vol. 73 No. 1, pp. 44-58.

Kunda, Z. and Schwartz, S.H. (1983), "Undermining intrinsic moral motivation: External reward and self-presentation", Journal of Personality and Social Psychology, Vol. 45 No. 4, pp. 763-771.

Kunter, M. (2015), "Exploring the Pay-What-You-Want payment motivation", Journal of Business Research [Online]. Available: http://www.sciencedirect.com/science/article/pii/ S0148296315001629. 
Lynn, M., and Oldenquist, A. (1986), "Egoistic and nonegoistic motives in social dilemmas", American Psychologist, Vol. 41 No. 5, p. 529.

Machado, F. and Sinha, R.K. (2012). The Viability of Pay What You Want Pricing. European Marketing Academy Conference. Lisbon, Portugal.

Mazumdar, T. and Papatla, P. (2000), "An investigation of reference price segments", Journal of Marketing Research, Vol. 37 No. 2, pp. 246-258.

Mazumdar, T., Raj, S.P. and Sinha, I. (2005), "Reference price research: review and propositions", Journal of Marketing, Vol. 69 No. 4, pp. 84-102.

Mendoza-Abarca, K.I. and Mellema, H.N. (2015), "Aligning economic and social value creation through pay-what-you-want pricing", Journal of Social Entrepreneurship [Online]. Available: http://www.tandfonline.com/doi/abs/10.1080/19420676.2015.1015437\#. VasXE00w92E.

McConnell, K. E. (1997), “Does altruism undermine existence value?” Journal of Environmental Economics and Management, Vol.32, No. 1, pp. 22-37.

Riener, G. and Traxler, C. (2012), "Norms, moods, and free lunch: Longitudinal evidence on payments from a Pay-What-You-Want restaurant", The Journal of Socio-Economics, Vol. 41 No. 4, pp. 476-483.

Roy, R. (2015), "An Insight into Pay-what-you-want Pricing", Marketing Intelligence \& Planning [Online]. Available: http://espace.library.curtin.edu.au/R?func=dbin-jumpfull\&local_base $=$ gen 01 -era02\&object_id $=213002$.

Rushton, J. P., and Sorrentino, R. M. (1981), Altruism and helping behavior, (Eds.). Hillsdale, NJ: Erlbaum.

Ryan, R.M. and Deci, E.L. (2000), "Intrinsic and extrinsic motivations: Classic definitions and new directions", Contemporary educational psychology, Vol. 25 No. 1, pp. 54-67.

Schmidt, K.M., Spann, M. and Zeithammer, R. (2014), "Pay what you want as a marketing strategy in monopolistic and competitive markets", Management Science, Vol. 61 No. 6, pp. 1217-1236.

Sharma, P. (2011), "Demystifying Cultural Differences in Country-of-Origin Effects: Exploring the Moderating Roles of Product Type, Consumption Context, and Involvement", Journal of International Consumer Marketing, Vol. 23 No. 5, pp. 344-364.

Soetevent, A. R. (2005), "Anonymity in giving in a natural context-a field experiment in 30 churches”, Journal of public Economics, Vol. 89 No. 11, pp. 2301-2323.

Spann, M. and Tellis, G.J. (2006), "Does the Internet promote better consumer decisions? The case of name-your-own-price auctions", Journal of Marketing, Vol. 70 No. 1, pp. 65-78. 
Wakefield, K. L. and Inman, J. J. (2003), "Situational price sensitivity: the role of consumption occasion, social context and income", Journal of Retailing, Vol. 79 No. 4,pp.199-212.

Winer, R.S. (1986), "A reference price model of brand choice for frequently purchased products", Journal of consumer research, Vol. No. pp. 250-256. 
Figure I. Conceptual model

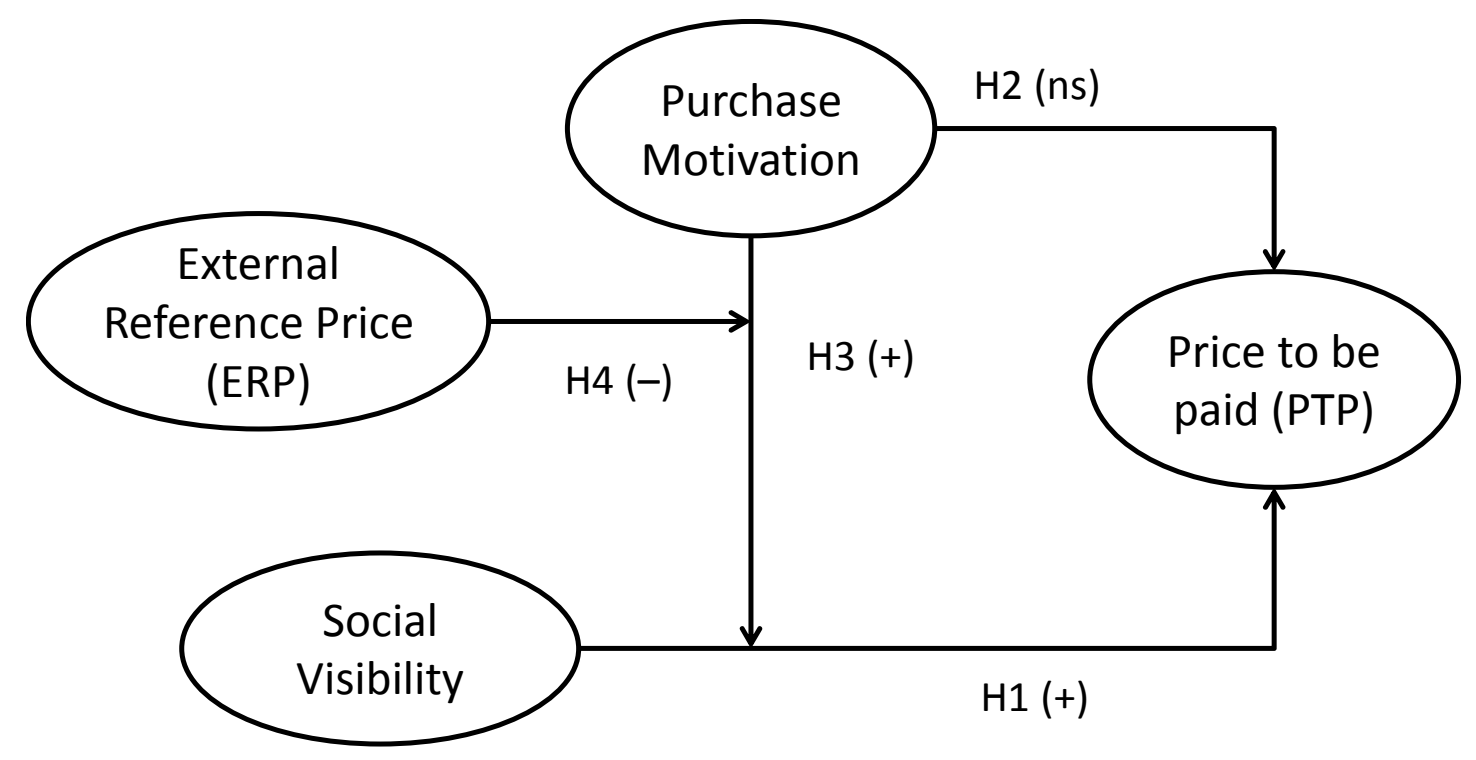


Figure II. Social Visibility X Purchase Motivation Interaction (Study 1)

\section{Without ERP}

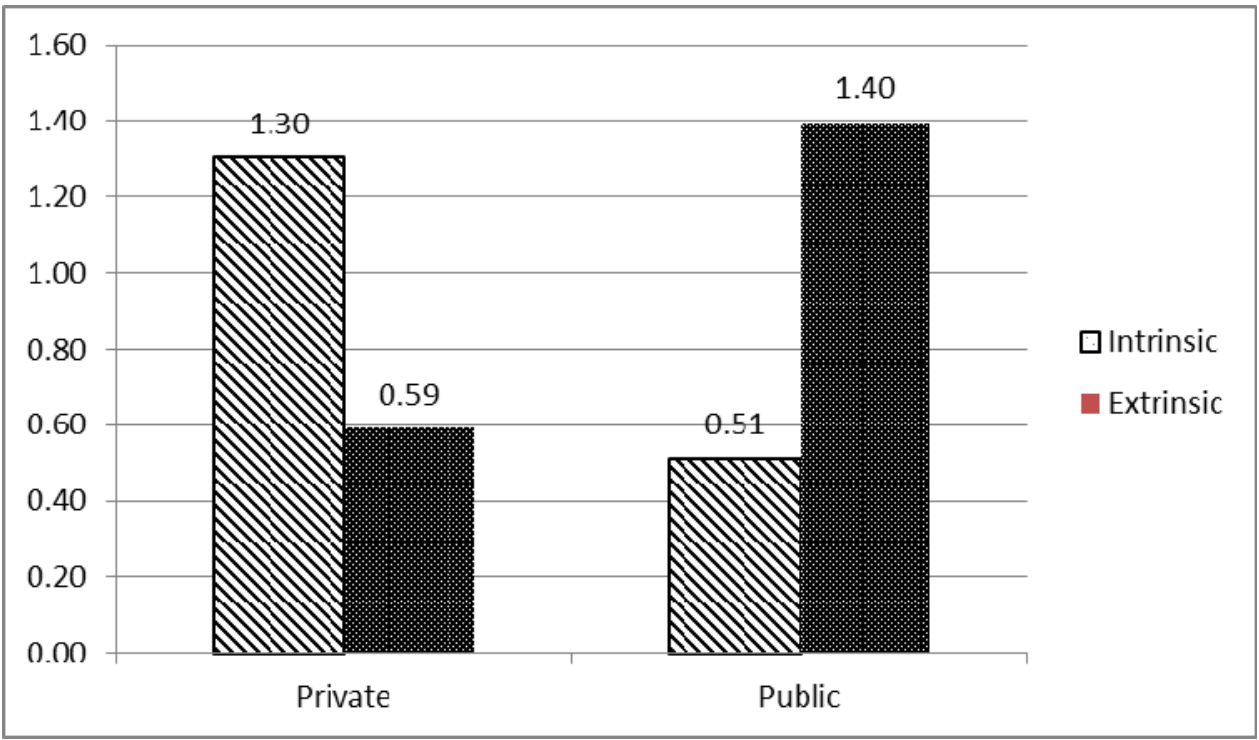

With ERP

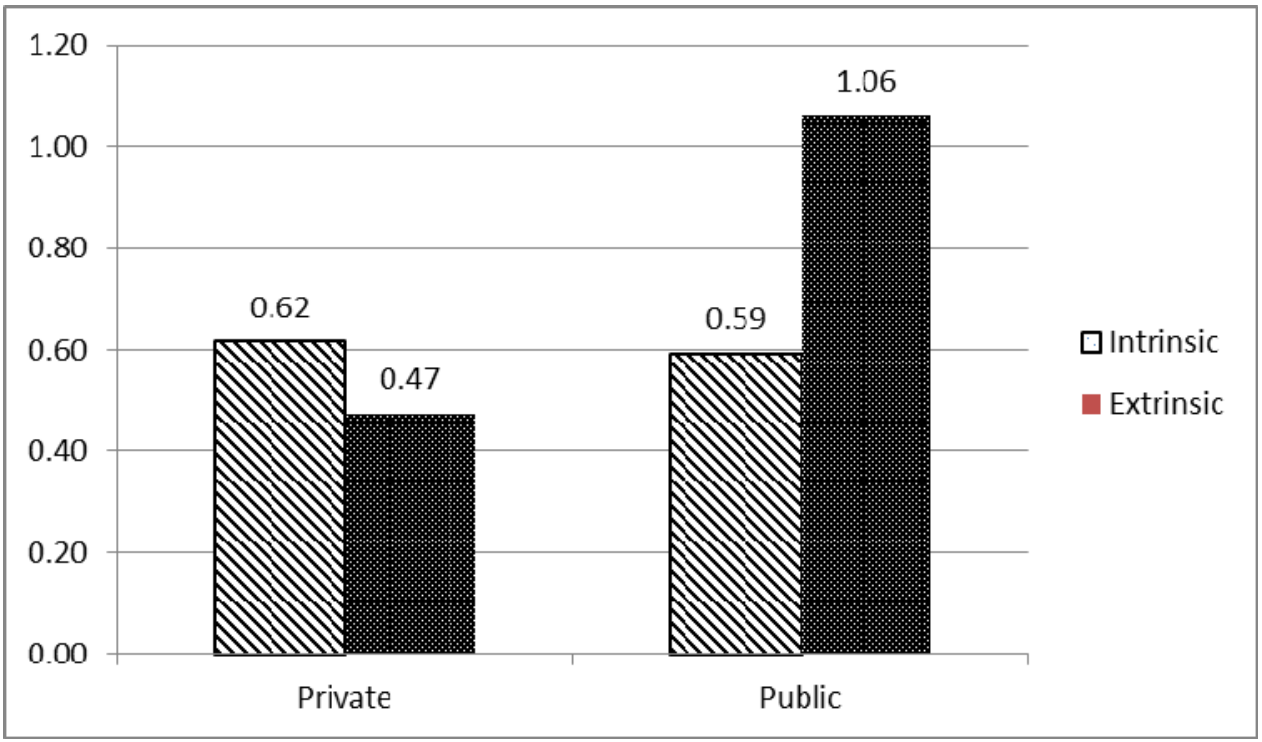


Figure III. Social Visibility X Purchase Motivation Interaction (Study 2)

\section{Without ERP}

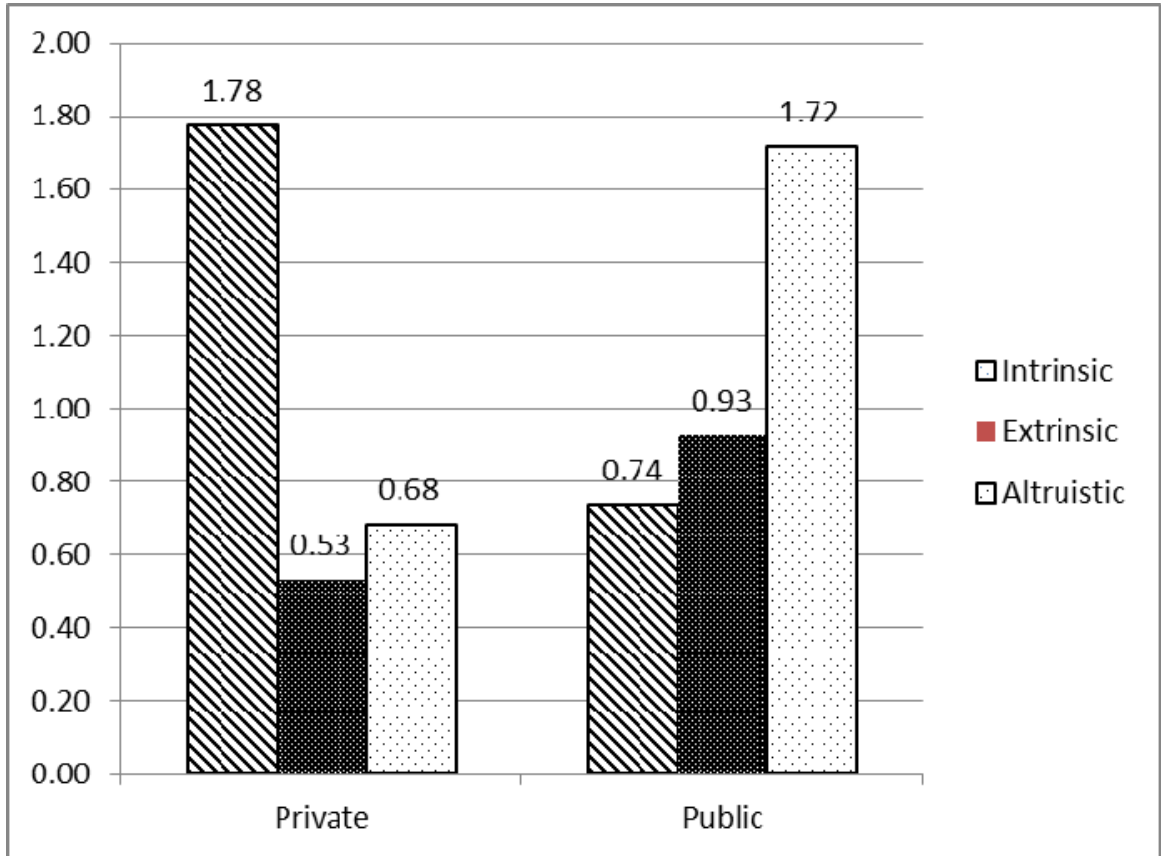

With ERP

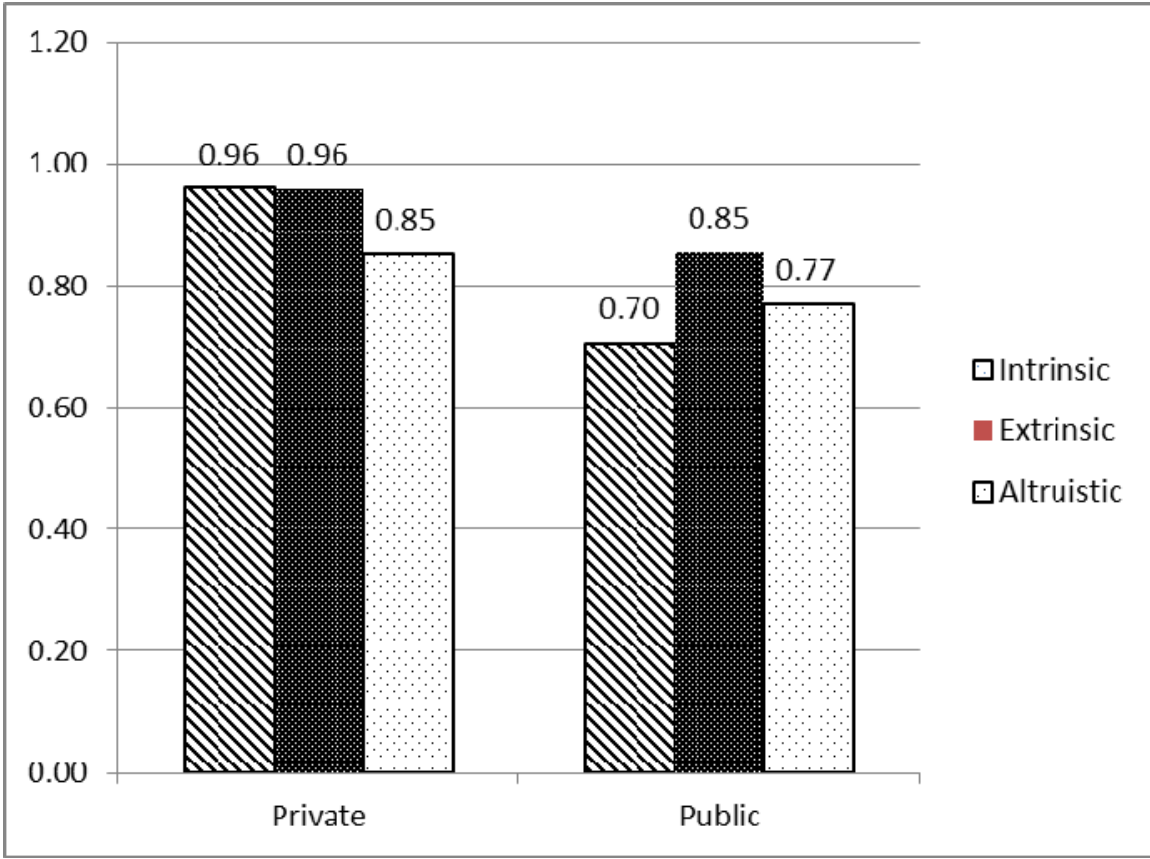


Table I. Samples composition (demographics)

\begin{tabular}{|c|c|c|}
\hline Demographics & Study $1(N=124)$ & Study $2(N=435)$ \\
\hline $\begin{array}{l}\text { Gender } \\
\text { Male } \\
\text { Female }\end{array}$ & $\begin{array}{l}59(47.6 \%) \\
65(52.4 \%)\end{array}$ & $\begin{array}{l}238(54.7 \%) \\
197(45.3 \%)\end{array}$ \\
\hline $\begin{array}{l}\text { Age } \\
<21 \text { years } \\
21-30 \text { years } \\
31-40 \text { years } \\
41-50 \text { years } \\
51-60 \text { years } \\
>60 \text { years }\end{array}$ & $\begin{array}{c}32(25.8 \%) \\
78(62.9 \%) \\
9(7.3 \%) \\
5(4.0 \%) \\
\text { NA } \\
\text { NA }\end{array}$ & $\begin{array}{c}\text { NA } \\
91(20.9 \%) \\
89(20.5 \%) \\
86(19.8 \%) \\
86(19.8 \%) \\
83(19.1 \%)\end{array}$ \\
\hline $\begin{array}{l}\text { Monthly Income } \\
<=\$ 1000 \\
\$ 1001-\$ 2000 \\
\$ 2001-\$ 3000 \\
\$ 3001-\$ 4000 \\
\$ 4001-\$ 5000 \\
>\$ 5000\end{array}$ & $\begin{array}{c}83(66.9 \%) \\
35(28.2 \%) \\
6(4.8 \%) \\
\text { NA } \\
\text { NA } \\
\text { NA }\end{array}$ & $\begin{array}{c}98(22.5 \%) \\
107(24.6 \%) \\
61(14.0 \%) \\
64(14.7 \%) \\
56(12.9 \%) \\
49(11.3 \%)\end{array}$ \\
\hline $\begin{array}{l}\text { Occupation } \\
\text { Unemployed } \\
\text { Part-time employed } \\
\text { Full-time employed } \\
\text { Self/Business } \\
\text { Retired } \\
\text { Housewife } \\
\text { Student } \\
\text { Others }\end{array}$ & $\begin{array}{c}\text { NA } \\
\text { NA } \\
\text { NA } \\
\text { NA } \\
\text { NA } \\
\text { NA } \\
124(100.0 \%) \\
\text { NA }\end{array}$ & $\begin{array}{c}58(13.3 \%) \\
83(19.1 \%) \\
133(30.6 \%) \\
37(8.5 \%) \\
61(14.0 \%) \\
34(7.8 \%) \\
\text { NA } \\
29(6.7 \%)\end{array}$ \\
\hline $\begin{array}{l}\text { Gym Membership } \\
\text { No } \\
\text { Yes }\end{array}$ & $\begin{array}{l}\text { NA } \\
\text { NA }\end{array}$ & $\begin{array}{l}203(46.7 \%) \\
232(53.3 \%)\end{array}$ \\
\hline $\begin{array}{l}\text { Gym Usage } \\
\text { Never } \\
\text { Rarely } \\
\text { Occasionally } \\
\text { Sometimes } \\
\text { Often } \\
\text { Frequently } \\
\text { Regularly }\end{array}$ & $\begin{array}{l}\text { NA } \\
\text { NA } \\
\text { NA } \\
\text { NA } \\
\text { NA } \\
\text { NA } \\
\text { NA }\end{array}$ & $\begin{array}{c}227(52.2 \%) \\
59(13.6 \%) \\
35(8.0 \%) \\
26(6.0 \%) \\
32(7.4 \%) \\
49(11.3 \%) \\
7(1.6 \%)\end{array}$ \\
\hline
\end{tabular}


Table II. Scales summary (Study 1)

\begin{tabular}{|c|c|c|c|c|c|}
\hline & Scale Items & $\lambda$ & $\alpha$ & $\mathbf{M}$ & SD \\
\hline $\begin{array}{l}\text { INT1 } \\
\text { INT2 } \\
\text { INT3 } \\
\text { INT4 }\end{array}$ & $\begin{array}{l}\text { Intrinsic purchase motivation } \\
\text { I think working out in this gym will help me - } \\
\quad \ldots \text { improve my fitness. } \\
\text {... gain strength. } \\
\text {... build stamina. } \\
\text {... lose weight. }\end{array}$ & $\begin{array}{l}0.75 \\
0.81 \\
0.79 \\
0.57\end{array}$ & $\begin{array}{l}0.56 \\
0.66 \\
0.62 \\
0.33\end{array}$ & $\begin{array}{l}5.52 \\
5.28 \\
5.09 \\
5.16\end{array}$ & $\begin{array}{l}1.16 \\
1.21 \\
1.22 \\
1.41\end{array}$ \\
\hline $\begin{array}{l}\text { EXT1 } \\
\text { EXT2 } \\
\text { EXT3 } \\
\text { EXT4 }\end{array}$ & $\begin{array}{l}\text { Extrinsic purchase motivation } \\
\text { I think working out in this gym will help me - } \\
\ldots \text { get back in shape. } \\
\text {... look good. } \\
\text {... improve my appearance. } \\
\text {... get a toned body. }\end{array}$ & $\begin{array}{l}0.79 \\
0.71 \\
0.76 \\
0.76\end{array}$ & $\begin{array}{l}0.64 \\
0.50 \\
0.57 \\
0.57\end{array}$ & $\begin{array}{l}5.44 \\
5.23 \\
5.14 \\
5.18\end{array}$ & $\begin{array}{l}1.16 \\
1.31 \\
1.41 \\
1.25\end{array}$ \\
\hline $\begin{array}{l}\text { INV1 } \\
\text { INV2 } \\
\text { INV3 } \\
\text { INV4 } \\
\text { INV5 } \\
\text { INV6 }\end{array}$ & $\begin{array}{l}\text { Involvement } \\
\text { I work out in a gym regularly. } \\
\text { I am very familiar with working out in a gym. } \\
\text { I am very knowledgeable about working out in a gym. } \\
\text { I can give people advice about working out in a gym. } \\
\text { I am able to judge about the quality facilities in a gym. } \\
\text { Working out in a gym is an important part of my } \\
\text { lifestyle. }\end{array}$ & $\begin{array}{l}0.81 \\
0.94 \\
0.97 \\
0.85 \\
0.83 \\
0.78\end{array}$ & $\begin{array}{l}0.65 \\
0.89 \\
0.94 \\
0.72 \\
0.68 \\
0.61\end{array}$ & $\begin{array}{l}3.70 \\
4.45 \\
4.15 \\
3.62 \\
4.16 \\
3.69\end{array}$ & $\begin{array}{l}1.93 \\
1.93 \\
1.86 \\
1.88 \\
1.98 \\
1.91\end{array}$ \\
\hline $\begin{array}{l}\text { PCO1 } \\
\text { PCO2 } \\
\text { PCO3 }\end{array}$ & $\begin{array}{l}\text { Price Consciousness } \\
\text { Before I buy a product, I often check the prices at } \\
\text { different retailers to obtain the best benefits. } \\
\text { I usually purchase items on sale only. } \\
\text { I usually purchase the cheapest item. }\end{array}$ & $\begin{array}{l}0.44 \\
\\
0.77 \\
0.85\end{array}$ & $\begin{array}{l}0.19 \\
0.59 \\
0.65\end{array}$ & $\begin{array}{l}5.65 \\
4.33 \\
4.00\end{array}$ & $\begin{array}{l}1.25 \\
1.68 \\
1.61\end{array}$ \\
\hline $\begin{array}{l}\text { SDR1 } \\
\text { SDR2 } \\
\text { SDR3 }\end{array}$ & $\begin{array}{l}\text { Social Desirability } \\
\text { There have been occasions when I took advantage of } \\
\text { someone. } \\
\text { I sometimes feel resentful when I don't get my way. } \\
\text { I sometimes try to get even rather than forgive and } \\
\text { forget. }\end{array}$ & $\begin{array}{l}0.50 \\
0.75 \\
0.76\end{array}$ & $\begin{array}{l}0.25 \\
0.56 \\
0.58\end{array}$ & $\begin{array}{l}3.86 \\
4.25 \\
3.84\end{array}$ & $\begin{array}{l}1.59 \\
1.36 \\
1.65\end{array}$ \\
\hline PTP1 & Price to be paid 1 (AU\$ - Australian Dollars) & -- & -- & 13.49 & 13.23 \\
\hline IRP & Internal reference price (AU\$ - Australian Dollars) & -- & -- & 22.68 & 20.89 \\
\hline PTP2 & Price to be paid 2 (AU\$ - Australian Dollars) & -- & -- & 10.43 & 9.71 \\
\hline
\end{tabular}

( $\lambda=$ factor loading, $\alpha=$ squared multiple correlation, $\mathrm{M}=$ mean, $\mathrm{SD}=$ standard deviation)

Note: Items INT4, PCO1 \& SDR1 (in italics) were dropped due to poor reliability. 
Table III. Correlations table (Study 1)

\begin{tabular}{lcccccccc}
\hline Constructs & INT & EXT & INV & PCO & SDR & PTP1 & IRP & PTP2 \\
\hline Intrinsic Motivation (INT) & 1.00 & - & - & - & - & - & - & - \\
Extrinsic Motivation (EXT) & $.59^{* * *}$ & 1.00 & - & - & - & - & - & - \\
Involvement (INV) & $.23^{* *}$ & $.18^{*}$ & 1.00 & - & - & - & - & - \\
Price Consciousness (PCO) & -.17 & -.06 & -.01 & 1.00 & - & - & - & - \\
Social Desirability (SDR) & -.03 & -.11 & .13 & -.04 & 1.00 & - & - & - \\
Price to be paid 1 (PTP1) & -.14 & .00 & $-.20^{*}$ & .07 & .03 & 1.00 & - & - \\
Internal Reference Price (IRP) & -.07 & -.03 & $-.30^{* *}$ & .17 & .01 & $.50^{* * *}$ & 1.00 & - \\
Price to be paid 2 (PTP2) & .04 & .11 & .02 & .05 & .10 & $.35^{* *}$ & $.27^{* *}$ & 1.00 \\
\hline Composite Reliability & .80 & .87 & .95 & .80 & .76 & NA & NA & NA \\
\hline $\begin{array}{l}\text { Average Variance Extracted } \\
\text { (AVE) }\end{array}$ & .57 & .54 & .75 & .66 & .57 & NA & NA & NA \\
\hline & $p<.05$, & ${ }^{* *} p<.01,{ }^{* * *} p<.001$ & & & &
\end{tabular}


Table IV. Three-way Mixed ANOVA results (Study 1)

\begin{tabular}{lcccccc}
\hline & \multicolumn{3}{c}{ ERP Absent } & \multicolumn{3}{c}{ ERP Present } \\
& (Dependent Variable & RATIO1) & \multicolumn{2}{c}{ (Dependent Variable $=$ RATIO2) } \\
\hline & $\begin{array}{l}\text { Private } \\
(\mathbf{N = 6 1 )}\end{array}$ & $\begin{array}{c}\text { Public } \\
(\mathbf{N}=63)\end{array}$ & $\begin{array}{c}\text { Total } \\
(\mathbf{N = 1 2 4 )}\end{array}$ & $\begin{array}{c}\text { Private } \\
(\mathbf{N}=61)\end{array}$ & $\begin{array}{c}\text { Public } \\
(\mathbf{N}=63)\end{array}$ & $\begin{array}{c}\text { Total } \\
(\mathbf{N}=\mathbf{1 2 4})\end{array}$ \\
\hline Intrinsic & 1.30 & 0.51 & .89 & 0.62 & 0.59 & 0.60 \\
$(\mathbf{N = 5 7 )}$ & $(2.19)$ & $(0.28)$ & $(1.58)$ & $(0.55)$ & $(0.28)$ & $(0.43)$ \\
Extrinsic & 0.59 & 1.40 & 0.97 & 0.47 & 1.06 & 0.76 \\
$\mathbf{( N = 6 7 )}$ & $(0.38)$ & $(2.26)$ & $(1.62)$ & $(0.39)$ & $(2.00)$ & $(1.43)$ \\
Total & 0.93 & 0.94 & 0.94 & 0.54 & 0.82 & 0.68 \\
$\mathbf{( N = 1 2 4 )}$ & $(1.57)$ & $(1.64)$ & $(1.60)$ & $(0.47)$ & $(1.42)$ & $(1.06)$ \\
\hline
\end{tabular}

Note: Figures in parentheses represent standard deviation. 
Table V. Scales summary (Study 2)

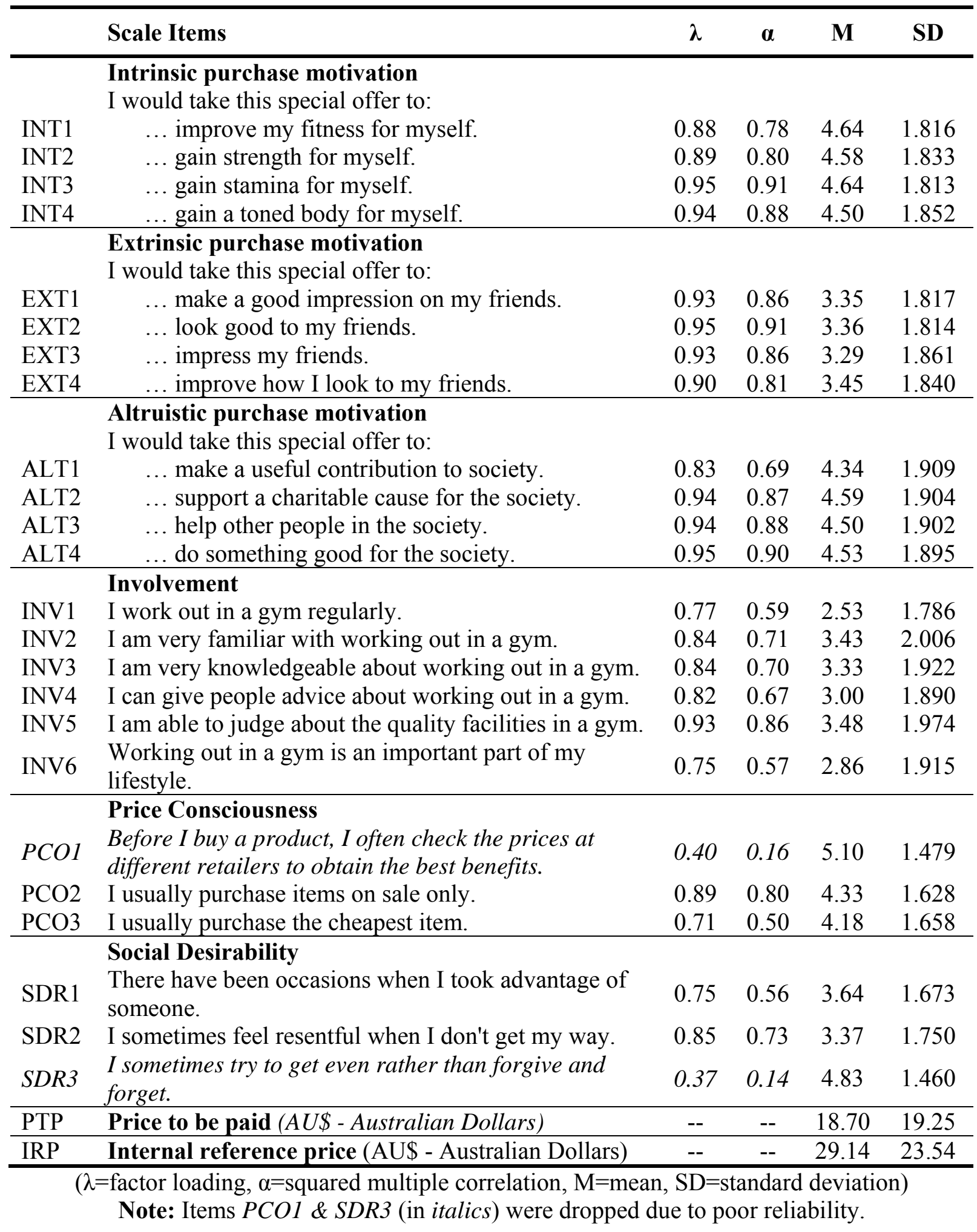


Table VI. Correlations table (Study 2)

\begin{tabular}{lcccccccc}
\hline Constructs & INT & EXT & ALT & INV & PCO & SDR & PTP & IRP \\
\hline Intrinsic Motivation (INT) & 1.00 & - & - & - & - & - & - & - \\
Extrinsic Motivation (EXT) & $.38^{* * *}$ & 1.00 & - & - & - & - & - & - \\
Altruistic Motivation (ALT) & $.62^{* * *}$ & $.38^{* * *}$ & 1.00 & - & - & - & - & - \\
Involvement (INV) & $.38^{* * *}$ & $.47^{* * *}$ & $.31^{* * *}$ & 1.00 & - & - & - & - \\
Price Consciousness (PCO) & $.24^{* *}$ & $.17^{* *}$ & $.18^{* *}$ & $.16^{* *}$ & 1.00 & - & - & - \\
Social Desirability (SDR) & $.37^{* * *}$ & $.38^{* * *}$ & $.28^{* *}$ & $.40^{* *}$ & $.38^{* *}$ & 1.00 & - & - \\
Price to be paid (PTP) & $.13^{* *}$ & $.29^{* *}$ & $.17^{* *}$ & $.18^{* *}$ & -.01 & .07 & 1.00 & - \\
Internal Reference Price (IRP) & .08 & $.16^{* *}$ & $.09^{*}$ & -.02 & -.03 & .04 & $.60^{* * *}$ & 1.00 \\
\hline Composite Reliability (CR) & .95 & .96 & .95 & .93 & .78 & .78 & NA & NA \\
\hline $\begin{array}{l}\text { Average Variance Extracted } \\
\text { (AVE) }\end{array}$ & .83 & .86 & .84 & .68 & .65 & .64 & NA & NA \\
\hline & $p<.05,{ }^{* *} p<.019^{* * *} p<.001$ & & & &
\end{tabular}


Table VII. Three-way between-subjects ANOVA results (Study 2)

Dependent Variable $=$ RATIO $($ PTP/IRP $)$

\begin{tabular}{|c|c|c|c|c|c|c|c|c|c|}
\hline & \multicolumn{3}{|c|}{ ERP Absent } & \multicolumn{3}{|c|}{ ERP Present } & \multicolumn{3}{|c|}{ Overall } \\
\hline & $\begin{array}{c}\text { Private } \\
(\mathrm{N}=216) \\
\end{array}$ & $\begin{array}{c}\text { Public } \\
(\mathrm{N}=219)\end{array}$ & $\begin{array}{c}\text { Total } \\
(\mathrm{N}=\mathbf{4 3 5}) \\
\end{array}$ & $\begin{array}{c}\text { Private } \\
(\mathrm{N}=216) \\
\end{array}$ & $\begin{array}{c}\text { Public } \\
(\mathrm{N}=219) \\
\end{array}$ & $\begin{array}{c}\text { Total } \\
(\mathrm{N}=\mathbf{4 3 5}) \\
\end{array}$ & $\begin{array}{c}\text { Private } \\
(\mathrm{N}=216) \\
\end{array}$ & $\begin{array}{c}\text { Public } \\
(\mathrm{N}=219) \\
\end{array}$ & $\begin{array}{c}\text { Total } \\
(\mathrm{N}=435) \\
\end{array}$ \\
\hline $\begin{array}{l}\text { Intrinsic } \\
(\mathrm{N}=142)\end{array}$ & $\begin{array}{c}1.78 \\
(3.06)\end{array}$ & $\begin{array}{c}0.74 \\
(0.81)\end{array}$ & $\begin{array}{c}1.23 \\
(2.24)\end{array}$ & $\begin{array}{c}0.96 \\
(1.14)\end{array}$ & $\begin{array}{c}0.70 \\
(0.56)\end{array}$ & $\begin{array}{c}0.83 \\
(0.90)\end{array}$ & $\begin{array}{c}1.36 \\
(2.31)\end{array}$ & $\begin{array}{c}0.72 \\
(0.69)\end{array}$ & $\begin{array}{c}1.03 \\
(1.71)\end{array}$ \\
\hline $\begin{array}{l}\text { Extrinsic } \\
(\mathrm{N}=144)\end{array}$ & $\begin{array}{c}0.53 \\
(0.32)\end{array}$ & $\begin{array}{c}0.93 \\
(1.63)\end{array}$ & $\begin{array}{c}0.73 \\
(1.18)\end{array}$ & $\begin{array}{c}0.96 \\
(1.15)\end{array}$ & $\begin{array}{c}0.85 \\
(0.79)\end{array}$ & $\begin{array}{c}0.90 \\
(0.98)\end{array}$ & $\begin{array}{c}0.74 \\
(0.87)\end{array}$ & $\begin{array}{c}0.89 \\
(1.26)\end{array}$ & $\begin{array}{c}0.82 \\
(1.08)\end{array}$ \\
\hline $\begin{array}{l}\text { Altruistic } \\
(\mathrm{N}=149)\end{array}$ & $\begin{array}{c}0.68 \\
(0.70)\end{array}$ & $\begin{array}{c}1.72 \\
(2.87)\end{array}$ & $\begin{array}{c}1.19 \\
(2.11)\end{array}$ & $\begin{array}{c}0.85 \\
(0.51)\end{array}$ & $\begin{array}{c}0.77 \\
(0.58)\end{array}$ & $\begin{array}{c}0.81 \\
(0.54)\end{array}$ & $\begin{array}{c}0.77 \\
(0.61)\end{array}$ & $\begin{array}{c}1.23 \\
(2.08)\end{array}$ & $\begin{array}{c}1.00 \\
(1.54)\end{array}$ \\
\hline $\begin{array}{l}\text { Total } \\
(N=435)\end{array}$ & $\begin{array}{c}0.98 \\
(1.84)\end{array}$ & $\begin{array}{c}1.13 \\
(1.98)\end{array}$ & $\begin{array}{c}1.05 \\
(1.91)\end{array}$ & $\begin{array}{c}0.92 \\
(0.97)\end{array}$ & $\begin{array}{c}0.78 \\
(0.65)\end{array}$ & $\begin{array}{c}0.85 \\
(0.82)\end{array}$ & $\begin{array}{c}0.94 \\
(1.43)\end{array}$ & $\begin{array}{c}0.96 \\
(1.47)\end{array}$ & $\begin{array}{c}0.95 \\
(1.45)\end{array}$ \\
\hline
\end{tabular}

Note: Figures in each cell shows the average value of RATIO and its standard deviation. 